\title{
Green and Clean as Issue on Women's Movement in Surabaya
}

\author{
$1^{\text {st }}$ Maya Mustika Kartika Sari \\ Pancasila and Civic Education \\ Department \\ Faculty of Social Sciences and Law \\ Universitas Negeri Surabaya \\ Surabaya, Indonesia \\ mayamustika@unesa.ac.id
}

\author{
$2^{\text {nd }}$ Oksiana Jatiningsih \\ Pancasila and Civic Education \\ Department \\ Faculty of Social Sciences and Law \\ Universitas Negeri Surabaya \\ Surabaya, Indonesia \\ oksianajatiningsih@unesa.ac.id
}

\author{
$3^{\text {rd }}$ Listyaningsih \\ Pancasila and Civic Education \\ Department \\ Faculty of Social Sciences and Law \\ Universitas Negeri Surabaya \\ Surabaya, Indonesia \\ listyaningsih@unesa.ac.id
}

\begin{abstract}
Discourse on gender phenomena has always been an interesting topic. Various social studies are used to respond to gender phenomena and realities in society. The women's movement is expected to create a new awareness of gender equality that can lead to just social relationships. This article is based on research results that reveal the process of social cohesion among women's activist groups in Surabaya, especially on the issues raised in building an identity in a collective movement. According to Durkheim, collective identity is an important factor in developing the function of social integration. It can be seen from the collective activities that develop in groups. To understand the collective activities of the women's movement, it is important to know the main issues that they make reference to on the move. This is the main focus that will be stated in this article
\end{abstract}

\section{Keywords - women, social movements, environmental issues}

\section{INTRODUCTION}

Democratization that blossomed in Indonesia, it encourages hardening in relations between groups or between countries and citizens. In the Parson analysis framework, it can be explained that the main function of the life alliance is integrating [1]. The integrative function includes two things. First, define social identity and membership criteria in the community. Second, creating a normative system that regulates the relationship between members of society or various different sub-units in society. So, social groups tend to refer to identity equality.

The current development of society shows not only the pattern of broad group integration but also the opposite, further strengthening and affirming the existence of small groups that tend to be more exclusive. The fundamental change in the grouping of the community creates varied disparities and group characteristics. In such conditions, the relationship between groups is determined by the interests of each. This has led to the emergence of social groups that base themselves on traditional as well as modern identities.

Indonesian society is driven by two motives of groups that are interdependent but also different and contradictory. The first side is a primordial bond, which demands that the search for identity and desire for identity be recognized openly as social affirmation. The other side is the practical desire to build a modern, dynamic and efficient state, which means a reduction in primordial sentiment that leads to public order. The attraction can be accommodated with solidarity. According to Parera and Koekerits, solidarity is actually an integrated feeling experienced by all individuals as part of a group[2]. At the micro level, groups and group solidarity always have boundaries that differentiate from other groups. Every community group (even those based on primordial ties) actually has a civility element, which is an element for human relations. This element is wealth in each group or nation because it voices the theme of togetherness as well as respect for the interests of individuals and group

In early 2002, in Surabaya emerged the phenomenon of environmental cadres. They are housewives who are active in managing the environment and conducting community empowerment activities to manage the surrounding environment they live in. They were helped a lot by two nongovernmental organizations engaged in the environment, namely Uli Peduli and Pusdakota. Uli Peduli is a nongovernmental organization supported by multinational companies Unilever and Pusdakota are activist groups engaged in the environmental sector. The cadres are involved in voluntary waste segregation activities. They also describe and independently self-calibrate the programs they want to run. That is, the programs undertaken derived from the thoughts and public participation accommodated by the cadres. The built social bond is a horizontal bond between members of the care and other members of society. Therefore the existence of these environmental cadres is increasingly existed both in terms of quantity and projects carried out.

Members of the cadre group are all women, housewives, in a heterogeneous urban culture in terms of education, race, ethnicity and religion. Most of the level of education is senior high school and they are not women who work outside the home.

\section{RESEARCH METHODS}

The research method that has been used is a qualitative research, that is studying and analyzing the theme or issue that become the focus of research. This research focuses on the questions and the behavior of female environmental activists. That is about how they perceive themselves and their environment, and what things make them integrated 
into an environmental movement. Where, their background as housewives, is not oriented to roles in the public sphere but they are active in the public sphere. The data were obtained by means of participant observation in order to clarify the relationship between the conception and collective identity carried out by the housewives. and the method of indepth interview is used to find out what is hidden behind the behavior and actions of the informant.

\section{RESULTS AND DISCUSSION}

The group of environmental cadres is a collective of individuals who care about the waste problem. Environmental awareness, especially on the issue of waste management is a central idea of the caring character developed by environmental cadre groups. The activities of the environmental cadres include three aspects, namely (1) Reduce, that is reducing the volume of waste disposed to a temporary garbage disposal. The way it is done is to separate organic waste (wet waste / decompose waste) and inorganic waste (dry waste / non-decomposed waste). Organic waste is included in the composter, whereas un-organic waste can be disposed of in the trash. (2) Reused, namely using or utilizing the results of waste disposal as much as possible so as to provide economic benefits. How to do is to sell the waste to the factory or just use the waste goods back. (3) Recycling, which is processing certain waste goods so that they become new products that have added value. The trick is to make the waste goods as raw materials in making new goods that have high economic value.

The collective identity of the cadre of the environment is built on the perceptions developed by members of the issues that developed at the time. The term environmental cadre is a label given during training in waste management. They have perceptions and believe that they are actually mandated as "warriors" of the environment. This is apparent in the statement of the subject stating that the environmental cadre is a volunteer or rescuer, in other words, the presence of environmental cadres is something that is needed and important its existence. Although the subject itself also questions the legitimacy of environmental cadres as an entity, it refuses to be called the action of the organization. So with all that doubt, according to the subject, the most appropriate definition is as a social activity.

\section{A. Green and Clean as Domestic Activities for Women}

The activities of environmental cadres are built in the green and clean concept, with fundamentals in three aspects of environmental management, namely reduce, reused, and recycling. Each of these aspects has implications for using activities that environmental cadres do. Collective activities carried out include the following.

- The activity of sorting waste is done as a personal activity that must be done by the housewife. If there is someone who does not do the sorting of garbage, it will be reprimanded by other cadre members/friends. The parameters are the type of waste that is dumped in the trash outside the house. If waste is disposed of more organic waste, it becomes an indicator that environmental cadres do not sort waste.

- Make maximum use of waste disposal results so as to provide economic benefits. The method used is to sell recyclable waste to the factory or reuse the waste items independently. The implication of activities conducted by the cadres is the cadre of the environment to organize garbage collection that can be recycled in the collective environmental scale of the house collectively and sell it to the collectors. The results are agreed to be used to buy seeds, pots, planting media, or composters which will be used for greening the environment.

- Creating creativity in the use of waste into valuable new products, such as crafting flowers from bottle rubbish, tablecloths from straws, plastic waste umbrellas, and other items.

- Conduct waste utilization training and market waste products. Many residents are interested in processing waste but cannot market it. In this phase, environmental cadres facilitate by marketing the products in the exhibition and bazaar arena.

- Other activities carried out by the cadres in groups are greening and maintaining the cleanliness of the environment. Specifically, the activities include clearing and planting empty lands, crop arrangement on village roads, and roadside painting.

\section{B. Issues, Movements, Political Implications}

The spirit of environmental cadres in waste management refers to the spirit of green and clean. Ideas that arise in cadre activities focus on efforts to clean the environment from waste and create a beautiful environment by planting trees and greenery. it appears on the idea of being quite visionary like, free from the waste. This strengthens the consistency of cadres in waste management. But sometimes their spirits decline because of new ideas that appear less. So the idea is the key to the consistency of the environmental group's cadres. The activities of the cadres are motivated by the circulation of ideas from members who are disseminated from one cadre to another. Here is a description of the environmental activists in the form of activity table.

TABLE I. ACTIVITY IDEAS OF THE ENVIRONMENT CADRES

\begin{tabular}{|c|l|c|}
\hline No. & \multicolumn{1}{|c|}{ Activity Form } & The Main Issue \\
\hline 1. & Sort waste & $\begin{array}{c}\text { Efforts to reduce household } \\
\text { waste }\end{array}$ \\
\hline 2. & $\begin{array}{l}\text { Teach people to sort } \\
\text { waste }\end{array}$ & $\begin{array}{c}\text { Gain support collectively to } \\
\text { become a massive } \\
\text { movement }\end{array}$ \\
\hline 3. & $\begin{array}{l}\text { Collect the dry waste } \\
\text { and sell it to the } \\
\text { collectors }\end{array}$ & $\begin{array}{c}\text { Gain economic benefits } \\
\text { from waste }\end{array}$ \\
\hline 4. & $\begin{array}{l}\text { Utilizing waste in } \\
\text { handicraft products }\end{array}$ & $\begin{array}{c}\text { Benefit from greater } \\
\text { economic selling value from } \\
\text { the waste utilization process }\end{array}$ \\
\hline 5. & $\begin{array}{l}\text { Conducting training / } \\
\text { Course makes crafts } \\
\text { from garbage }\end{array}$ & $\begin{array}{c}\text { Dissemination of knowledge } \\
\text { about waste management }\end{array}$ \\
\hline 6. & $\begin{array}{l}\text { Environmental } \\
\text { arrangement through } \\
\text { reforestation } \\
\text { hygiene activities and }\end{array}$ & $\begin{array}{c}\text { Maintaining environmental } \\
\text { health and sustainable } \\
\text { environmental management } \\
\text { environmental } \\
\text { competitions }\end{array}$ \\
\hline 7.
\end{tabular}




\begin{tabular}{|c|l|c|}
\hline No. & \multicolumn{1}{|c|}{ Activity Form } & The Main Issue \\
\hline 8. & $\begin{array}{l}\text { Management of } \\
\text { household wastewater }\end{array}$ & $\begin{array}{c}\text { Manage liquid waste by } \\
\text { involving others who are } \\
\text { competent }\end{array}$ \\
\hline 9. & $\begin{array}{l}\text { Communicate } \\
\text { environmental issues } \\
\text { with the relevant } \\
\text { government. }\end{array}$ & $\begin{array}{c}\text { Trying to get solutions } \\
\text { related to environmental } \\
\text { problems that cadres cannot } \\
\text { solve such as flooding } \\
\text { problems }\end{array}$ \\
\hline
\end{tabular}

The form of "movement" is more critical to the effort to create awareness and community involvement in solving waste problems which at that time was one of the public problems. The group of environmental cadres becomes the mobilizer of the community in doing waste segregation and other efforts in environmental management. Within the framework of democracy, it is an incentive to participate in solving public problems.

There are two things that can be observed as facts in the reality. Firstly, that environmental cadre groups have been involved in efforts to resolve the waste problem that has become a public problem. Secondly, inviting the citizens simultaneously and continuously to participate and engage in these activities. The first fact, describes the participation of environmental cadres, while the second fact illustrates the urge of environmental cadre groups for citizens to participate.

The context of the political relations of citizens, what is done by the group of environmental cadres is a manifestation of democratic participation and civilian tolerance of active citizens. This is in line with the concept of community proposed by Anthony Giddens, that the community refers to practical tools to assist in the social and material renovation of neighborhoods, cities and local areas. Local group activities that encourage local initiatives and engagements indicate community renewal [3]. The community theme is fundamental to the new politics. Reflexive societies are characterized by a high degree of organization in community groups. The organization creates political participation and awareness at the local level, where communal energy directs communal goals towards a wider range through ways that benefit the local community and society as a whole.

The group of environmental cadres initially conducted social organizing through waste management activities, but the growing communal energy has led to economic and political activity. It is characterized by the disparity in the interaction conducted with various government institutions, political organizations, and non-governmental organizations. Voluntary work activities have expanded into an act of public participation. Inglehart mentions this with postmaterialism, where small groups with limitations and problems are able to empower themselves and earnestly prove the richness of people's lives [4]. Wealth is not only understood as the accumulation of matter and power but also an accumulation of care and support as a basic element of participation.

The demands of reforms have opened the way for people to think and act increasingly critical in the scrutiny of state power management that has deviated from a shared commitment between government and society. At almost the same time the state experiences a weakening of power as a result of the reduced level of public confidence and the strengthening of tensions among the political institutions within it so that the mechanism of development becomes impeded. It encourages local self-empowerment in the elements of society that allow the opening of public spaces for the development of civil society.

\section{Discussion}

New social movements emerge as alternatives to ideological principles, strategies, actions, or choices. Jean L Coehen called it the creation of a new identity in understanding the world and opposing the cultural rules of domination based on symbolic reasons [5]. It happens as a new social articulation that crystallizes new experiences and problems that are shared and faced together, as a result of the general disintegration of the experience based on the economy. According to Claus Offe [6], the new social movement can be seen as a politicized civil society institution. Rationalization of communication is an expression of the pattern of life that is able to expand public spaces, it is necessary efforts to oppose the pathological disturbance of world life which is represented based on systematic political and economic mechanisms. Offe also said that the actors or participants of the new social movements come from three main sectors: the new middle class, the old middle class elements (peasants, shop owners, art producers), and those who occupy the marginal positions that do not too involved in the job market, such as students, housewives, and retirees.

The development of this social movement is considered to have been able to encourage the process of democratization. The emergence of the civil rights struggle movement, the feminist movement, the human rights movement, the anti-racial movement, etc., does not reflect as a particular articulation of thought or ideology, but rather as a response to widespread social problems [7]. This is influenced by the emergence of movements that do not base their movement on class consciousness and certain ideology but on the identity and awareness of the problems faced by society. Empirically the social movement is characterized by the blurring of the boundaries of ideology, origin, social background, and other narrow things that hinder the unification of the will to make social change.

Fuentes and Frank refer to it as a grassroots (local) social movement, transitional towards socialism in the sense of trying to break the anti-colonialist and anti-political chain, meaning not to hold power at the institutional level but broadly democratic [8]. It is a key element in the emergence of civil society by seeking to protect, protest and increase the interests of its members. The emerging activities are a picture of a democratic process that can gradually strengthen and expand civil society. In this case, the social movement serves to contribute to the formation of public opinion and discussions of socio-political issues through the incorporation of ideas. In addition, the other function is to produce leaders who present the interests of society, as many of the independence movers become their country's leaders.

Governments should support individual freedom in a more positive sense as the ability to participate in society as full citizens. The communitarian perspective sees citizenship as a membership derived from an ethical community [9]. Communitarians support the concept of active citizenship in 
the sense of active participation in a community bound by values that are believed and respected together and for the common good. It is natural for citizens to join in joint actions with other citizens to achieve the common good.

Public virtue is a priority and free of individual and institutional desires [10]. Being a citizen means having a connection with the historical development of a society. Citizens are responsible when they are within the constraints permitted by the community (collective identity). Autonomy and individual judgment cannot exist without the foundation of togetherness [11]. In creating a common identity, the individual must be assimilated into the society it enters so that it can be accepted as a full member (eg, humanitarian association as the source of self-identity). The community can survive because of the loyalty and strength of individual members, and each individual gains the support and strength of his or her membership status in the community. Yet by the very act of asking the audience to participate in states that are either too elemental, or too absolute, or too self-absorbed, artistic engagement becomes a participatory event that can have an impact on how and why individuals and citizens are concerned with values of all kinds [12].

\section{CONCLUSION}

The social activities carried out by individuals and/or groups constitute a concrete and open political arena for every citizen. Politics becomes an open arena that can be entered by all people whether done intentionally or not. Political activities are not only dominated by political parties although formally political parties have a significant role in the circulation of power. The social activities of non-political parties and community organizations have great potential to serve as interest groups that serve the function of civil society. First, as complementary in which the elements of civil society have the activity of promoting prosperity to complement the role of the state as public servant. Second, as a substitute. That is, the civil society conducts a series of activities that have not or do not do the state in relation to an institution that serves the interests of the wider community. And thirdly, as a counter-state force or counterbalancing the state. Civil society advocates, mentoring, litigation, and even opposition practices to compensate for the hegemonic power of the state or at least to be an alternative discourse outside the state bureaucracy apparatus.

The group of environmental cadres is a representation of social activities that have implications in the functions of civil society. It is urgency (an important matter to be disclosed) within the framework of changing social and political structures. Environmental issues have an integrative value due to the fact that everyone stands on the same earth. The value is sustained by a global "climate" that encourages modern intellectuals and mass communications to develop real ideas and activities.

\section{ACKNOWLEDGMENT}

This research was supported by the Faculty of Law And Social Sciences, Universitas Negeri Surabaya. Thanks to the Universitas Negeri Surabaya, especially to Dean of the Faculty of Social Sciences and Law. Thank you also to colleagues Lecturer at the Faculty of Social Sciences and Law, Universitas Negeri Surabaya.

\section{REFERENCES}

[1] G. Ritzer and D. J. Goodman, Sociological Theory, 6th ed. McGrawHill, 2003.

[2] T. A. Hart, J. B. Gilstrap, and M. C. Bolino, "Organizational citizenship behavior and the enhancement of absorptive capacity," $J$. Bus. Res., vol. 69, no. 10, pp. 3981-3988, 2016.

[3] A. Giddens, The Third Way: The Renewal of Social Democracy. Wiley, 1999.

[4] A. Giddens, The Global Third Way Debate. Wiley, 2001.

[5] S. Bjerkaker, "Changing Communities. The Study Circle - For Learning and democracy," Procedia - Soc. Behav. Sci., vol. 142, pp. 260-267, 2014

[6] C. Offe, "Political Economy: Sociological Perspective," in A New Handbook of Political Science, R. Goodin and H. Klingeman, Eds. Oxford University Press, 1996.

[7] S. Childs and J. Withey, "The Substantive Representation of Women: The Case of the Reduction of VAT on Sanitary Products," Parliam. Aff., vol. 59, no. 1, pp. 10-23, 2006.

[8] V. Lowndes, L. Pratchett, and G. Stoker, "Local Political Participation: The Impact of Rules-in-Use," Public Adm., vol. 84, no. 3, pp. 539-561, 2006.

[9] B. Wampler and L. Avritzer, "Participatory Publics: Civil Society and New Institutions in Democratic Brazil," Comp. Polit., vol. 36, no. 3, pp. 291-312, 2004.

[10] I. Harbers, "Democratic Deepening in Third Wave Democracies: Experiments with Participation in Mexico City," Polit. Stud., vol. 55, pp. 38-58, 2007.

[11] U. Cheasakul and P. Varma, "The influence of passion and empowerment on organizational citizenship behavior of teachers mediated by organizational commitment," Contaduría y Adm., vol. 61, no. 3, pp. 422-440, 2016.

[12] L. E. Roupakia, "AArt-iculating' Affective Citizenship: Dionne Brand's What We All Long ForNo Title," Atl. J. Spanish Assoc. Anglo-American Stud., vol. 37, no. 1, pp. 31-50, 2015. 